\title{
Simulation Analysis on Navigation Indexes of Wanzhou Yangtze River Highway Bridge after the Anti-Collision Device Construction by Ship Model Test
}

\author{
Kui Yu1,2, Chao Tao ${ }^{3}$, Xuequan $\mathrm{Chu}^{3}$, Xiqin $\mathrm{Ma}^{1,2}$ \\ ${ }^{1}$ Southwestern Hydro Engineering Research Institute for Water Way, Chongqing Jiaotong University, Chongqing, China \\ ${ }^{2}$ Chongqing Engineering Research Center for Bridge Navigation Safety \& Anti-collision, Chongqing Jiaotong University, Chongqing, \\ China \\ ${ }^{3}$ School of River \& Ocean Engineering, Chongqing Jiaotong University, Chongqing, China \\ Email:434423352@qq.com
}

How to cite this paper: Yu, K., Tao, C., Chu, X.Q. and Ma, X.Q. (2016) Simulation Analysis on Navigation Indexes of Wanzhou Yangtze River Highway Bridge after the Anti-Collision Device Construction by Ship Model Test. Engineering, 8, 806-814.

http://dx.doi.org/10.4236/eng.2016.811072

Received: November 2, 2016

Accepted: November 19, 2016

Published: November 22, 2016

Copyright $\odot 2016$ by authors and Scientific Research Publishing Inc. This work is licensed under the Creative Commons Attribution International License (CC BY 4.0).

http://creativecommons.org/licenses/by/4.0/

\begin{abstract}
After the anti-collision facility construction of Wanzhou Yangtze River Highway Bridge, the conditions of navigation in bridge area are complex. In order to study the navigation conditions of the reach and layout optimization measures, ensuring the safety of the ship navigation test has been carried out on the ship model navigation in the bridge area. According to the requirements of the maximum safety limit of the ship model test, the paper puts forward the best route, the control method and the difficulty of navigation through the analysis of the test results, and finally gives the recommendations and suggestions.
\end{abstract}

\section{Keywords}

Wanzhou Yangtze River Highway Bridge, Anti-Collision Facility, Ship Model Test, Navigation Indexes

\section{(c) (i) Open Access}

\section{Introduction}

The study of bridge area navigation problem can effectively protect the safety of the bridge and the ship. In order to study navigation problems of bridge area more visually and scientifically, navigation flow conditions and navigation conditions were researched by using ship model and physical model [1]. For the accurate description of the ship model navigation test, two kinds of different criteria are given in the document [2]: rudder angle and minimum speed. The maximum rudder angle of the ship model 
test is generally set to 25 degrees, and $0.4 \mathrm{~m} / \mathrm{s}$ is taken as the minimum speed. Xiong and Liu [3] did the research on numerical prediction of propulsion factors of propelled ship model and full scale ship. The results are in good agreement with experiment data. In the document [4], scholars did the research on maneuverability calibration test of tow model for studying navigation of Three Gorges Project. The maneuverability similarity requirements of ship model with modified rudder (reduced rudder area by $28 \%$ ) can basically be satisfied for navigation study.

Chen Mingdong [5] studied on the navigation safety which is influenced by the construction of the bridge or some other building besides the river. It is pointed out that the navigation conditions of Wanzhou Yangtze River Highway Bridge's reach are complicated. Therefore, after the anti-collision facility construction of Wanzhou Yangtze River Highway Bridge, this paper does the research on the navigation condition of the reach and layout optimization measures, ensuring that the safety of the ship navigation test has been carried out on the ship model navigation in the bridge area.

\section{Engineering Situation}

Wanzhou Yangtze River Highway Bridge is in the perennial backwater area of the Three Gorges reservoir, which is a large arch bridge across the Yangtze River. The bridge is a reinforced concrete box arch bridge, which the arch and column are made of rectangular reinforced concrete thin-walled box structure. This bridge's resistance is weak along the direction of flow. When the Three Gorges reservoir's normal water, arch of the bridge will be partially submerged most of the time, and once the ship is out of control or off the course will collision arch and columns, which will cause arch bridge collapsed and serious safety accidents.

Therefore, in view of the bridge collision-avoidance capability is weak and bridge lanes is narrow and deep. So the existing anti-collision devices are not suit this bridge. We invent an arch self-floating anti-collision devices, which contain three major components: self-floating arch collision zone, buoys and guide. Its principle of operation is the collision of arch bridge surrounded by easily hit regional protection. And using the device deformation absorb energy in case of ship impact the device. Also arch collisions zone can be made to change the ship navigation direction when it collision the device with an angle. So this device can reduce impact forces effectively, protect maximize both the ships and bridges.

\section{Test Equipment}

\subsection{Hydraulic Model}

In this test, an undistorted model of 1:100 is employed to simulate the river reach of Wanzhou Yangtze River Highway Bridge. The simulation range is from the bridge axis above $2.5 \mathrm{~km}$ to the bridge axis below $2.5 \mathrm{~km}$.

\subsection{Ship Model Survey}

This experiment uses two kinds of ship models: $5000 \mathrm{t}$ and $1000 \mathrm{t}$ ship model. The main 
dimensions are showed in Table $1 \&$ Table 2.

\subsection{Measurement \& Control Equipment}

The CMH-3B ship model automatic test system is used to carry out the experiment. This system uses the laser to scan on ship motion by non-contact detection method. And a computer will telemeter the attitude of ship model and manipulate the elements synchronously, control the ship model and calculate the results automatically, then show the real-time graphics and calculation results in the screen. The system can timely display the test process with sufficient accuracy and high efficiency. And it can provide the conditions by high quality and swift progress of the test.

\section{Test Survey}

\subsection{Test Method}

According to the test requirement, the ship model is made, then tested and calibrated in the test pool. CMH-3B ship model automatic test system is used to do this test. And the remote control equipment is used to operate ship which is sailing in the corresponding segment of hydraulic model. Some navigation elements: track, speed, position and the drift angle of the ship model are telemetered by laser scanning. And the operation of propeller and rudder are telemetered by the CMJ-3 radio interface telemetry. Then data will be inputted computer automatically to process data, calculate and draw figure constantly.

Based on the comprehensive analysis of the ship model test results and the water flow condition, the advantages and disadvantages of the two schemes are compared, and the opinions and suggestions are put forward. In order to ensure the reliability of the ship model test results, each case must carry on more than one voyage test, then analysis of navigation conditions with its characteristic value.

Table 1. 5000 t class ship model survey (L-ship's length, B-ship's breadth, T-ship's draft).

\begin{tabular}{cccc}
\hline Parameter & Real ship & Ship model & Scale \\
\hline Ship dimension $(\mathrm{L} \times \mathrm{B} \times \mathrm{T})$ & $106 \mathrm{~m} \times 17.5 \mathrm{~m} \times 4.0 \mathrm{~m}$ & $106 \mathrm{~cm} \times 17.5 \mathrm{~cm} \times 4.0 \mathrm{~cm}$ & 100 \\
Ship displacement & $5620 \mathrm{t}$ & $5620 \mathrm{~g}$ & $1,000,000$ \\
Ship speed & $3.3 \mathrm{~m} / \mathrm{s}$ & $0.33 \mathrm{~m} / \mathrm{s}$ & 10 \\
Rudder angle & Left $35^{\circ}$ to right $35^{\circ}$ Step less steering ratio & \\
\hline
\end{tabular}

Table 2. 1000 t class ship model survey (L-ship's length, B-ship's breadth, T-ship's draft).

\begin{tabular}{cccc}
\hline Parameter & Real ship & Ship model & Scale \\
\hline Ship dimension $(\mathrm{L} \times \mathrm{B} \times \mathrm{T})$ & $75.5 \mathrm{~m} \times 12.0 \mathrm{~m} \times 2.6 \mathrm{~m}$ & $75.5 \mathrm{~cm} \times 12.0 \mathrm{~cm} \times 2.6 \mathrm{~cm}$ & 100 \\
Ship displacement & $1612 \mathrm{t}$ & $1612 \mathrm{~g}$ & $1,000,000$ \\
Ship speed & $3.3 \mathrm{~m} / \mathrm{s}$ & $0.33 \mathrm{~m} / \mathrm{s}$ & 10 \\
Rudder angle & Left $35^{\circ}$ to right $35^{\circ}$ step less steering ratio & \\
\hline
\end{tabular}




\subsection{Test Route Segment}

This test route segment of ship model navigation is located in the bridge district. The simulation range is from the upper reaches of the bridge axis $400 \mathrm{~m}$ to the lower reaches of the bridge axis $300 \mathrm{~m}$. The length of test section is $700 \mathrm{~m}$.

\subsection{Test Discharge}

In this paper, we test three kinds of discharge, namely $\mathrm{Q}=28,400 \mathrm{~m}^{3} / \mathrm{s}, \mathrm{Q}=37,800 \mathrm{~m}^{3} / \mathrm{s}$ $\& \mathrm{Q}=45,000 \mathrm{~m}^{3} / \mathrm{s}$ ( $\mathrm{Q}$ stand for the discharge in the bridge waterway).

\section{Ship Model Test Results \& Discussion}

The test results of ship model navigation is showed in Table 3.

Table 3 data show that after Wanzhou Yangtze River Highway bridge anti-collision facility is set, the maximum rudder angle and the maximum drift angle are increasing with discharges are increasing, and the minimum speed and average speed are decreasing with discharges are increasing in the three flow conditions of ship model test when the $1000 \mathrm{t}$ and $5000 \mathrm{t}$ ship sail in the bridge waterways. When the ship is sailing upstream, the minimum speed and the average speed decreases with the increase of the flow rate. The reason is that the vertical and horizontal flow in the bridge area is increasing when the discharge is increasing. So it will increase the difficulty of ship maneuvering.

\subsection{0 t Class Ship Model Test}

1) Upstream Situation

In $\mathrm{Q}=28,400 \mathrm{~m}^{3} / \mathrm{s}, \mathrm{Q}=37,800 \mathrm{~m}^{3} / \mathrm{s}$ and $\mathrm{Q}=45,000 \mathrm{~m}^{3} / \mathrm{s}$ these three kinds of flow

Table 3. The test results of ship model navigation (All data have been converted to prototype values).

\begin{tabular}{|c|c|c|c|c|c|c|c|c|c|}
\hline \multirow{2}{*}{$\begin{array}{l}\text { Ship's } \\
\text { Tonnage }\end{array}$} & \multirow{2}{*}{ Course } & \multirow{2}{*}{$\begin{array}{c}\text { Discharge } \\
\left(\mathrm{m}^{3} / \mathrm{s}\right)\end{array}$} & \multirow{2}{*}{$\begin{array}{l}\text { Maximum } \\
\text { rudder } \\
\text { angle }\left({ }^{\circ}\right)\end{array}$} & \multirow{2}{*}{$\begin{array}{l}\text { Maximum } \\
\text { drift } \\
\text { angle }\left({ }^{\circ}\right)\end{array}$} & \multicolumn{2}{|c|}{ Ship's speed $(\mathrm{m} / \mathrm{s})$} & \multirow{2}{*}{$\begin{array}{l}\text { Voyage } \\
(\mathrm{m})\end{array}$} & \multirow{2}{*}{$\begin{array}{l}\text { Sailing } \\
\text { time } \\
(\min )\end{array}$} & \multirow{2}{*}{$\begin{array}{c}\text { Average } \\
\text { ship's speed } \\
(\mathrm{m} / \mathrm{s})\end{array}$} \\
\hline & & & & & Max. & Min. & & & \\
\hline \multirow{6}{*}{$1000 \mathrm{t}$} & \multirow{3}{*}{ Upstream } & 28,400 & 15.84 & 6.67 & 3.35 & 3.03 & 640 & 3.37 & 3.17 \\
\hline & & 37,800 & 17.13 & 8.47 & 3.14 & 2.02 & 607 & 4.22 & 2.40 \\
\hline & & 45,000 & 19.50 & 16.38 & 2.95 & 1.73 & 614 & 4.72 & 2.17 \\
\hline & \multirow{3}{*}{ Downstream } & 28,400 & 11.03 & 19.15 & 4.72 & 3.87 & 626 & 2.23 & 4.69 \\
\hline & & 37,800 & 12.40 & 13.72 & 5.58 & 4.76 & 596 & 1.89 & 5.26 \\
\hline & & 45,000 & 15.91 & 9.15 & 5.68 & 4.41 & 609 & 1.83 & 5.56 \\
\hline \multirow{6}{*}{$5000 \mathrm{t}$} & \multirow{3}{*}{ Upstream } & 28,400 & 17.22 & 8.94 & 3.28 & 3.08 & 618 & 3.20 & 3.22 \\
\hline & & 37,800 & 20.46 & 11.75 & 3.18 & 2.17 & 602 & 4.03 & 2.49 \\
\hline & & 45,000 & 20.64 & 10.00 & 3.02 & 1.97 & 619 & 4.62 & 2.23 \\
\hline & \multirow{3}{*}{ Downstream } & 28,400 & 11.02 & 7.53 & 4.66 & 3.98 & 617 & 2.25 & 4.57 \\
\hline & & 37,800 & 12.83 & 3.67 & 5.35 & 4.21 & 608 & 1.92 & 5.29 \\
\hline & & 45,000 & 16.30 & 10.97 & 5.47 & 4.19 & 608 & 1.80 & 5.52 \\
\hline
\end{tabular}


test conditions, the ship sails upstream in the bridge waterway. Figure 1 shows the maximum rudder angle was $15.84^{\circ}, 17.13^{\circ}$ and $19.50^{\circ}$. These angles did not exceed the ship model test of rudder angle limit $\left(25^{\circ}\right)$. Figure 2 shows the minimum ship speed were $3.03 \mathrm{~m} / \mathrm{s}, 2.02 \mathrm{~m} / \mathrm{s}$ and $1.73 \mathrm{~m} / \mathrm{s}$, were significantly better than the minimum speed of ship model test safety limit $(0.4 \mathrm{~m} / \mathrm{s})$. Along with the increase of the discharge, the longitudinal and transverse velocity of the channel in the bridge area is also increased. That will inevitably lead to the increase of the speed of the ascending vessel and the difficulty of the operation.

2) Downstream Situation

In $\mathrm{Q}=28,400 \mathrm{~m}^{3} / \mathrm{s}, \mathrm{Q}=37,800 \mathrm{~m}^{3} / \mathrm{s}$ and $\mathrm{Q}=45,000 \mathrm{~m}^{3} / \mathrm{s}$ these three kinds of flow test conditions, the ship sails downstream in the bridge waterway. Figure 3 shows the maximum rudder angle was $11.03^{\circ}, 12.40^{\circ}$ and $15.91^{\circ}$. These angles did not exceed the ship model test of rudder angle limit $\left(25^{\circ}\right)$.

Ship model test results show that, after the anti-collision facility is set in the Wanzhou Yangtze River Highway Bridge, $1000 \mathrm{t}$ ship can safely pass through the bridge

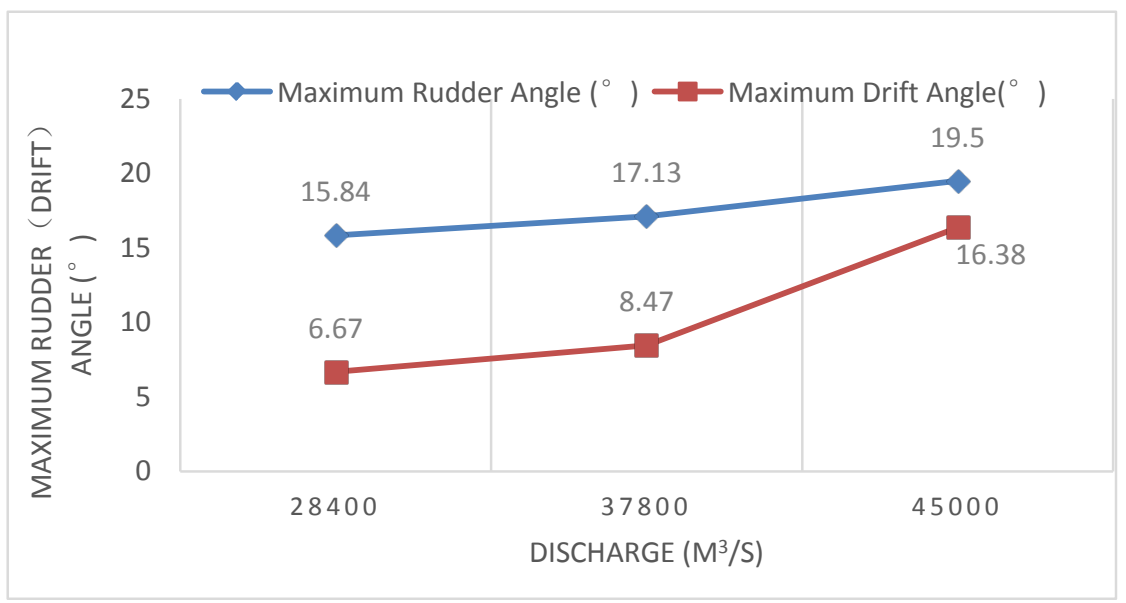

Figure 1. The maximum rudder \& drift angle with discharges (1000 t, upstream).

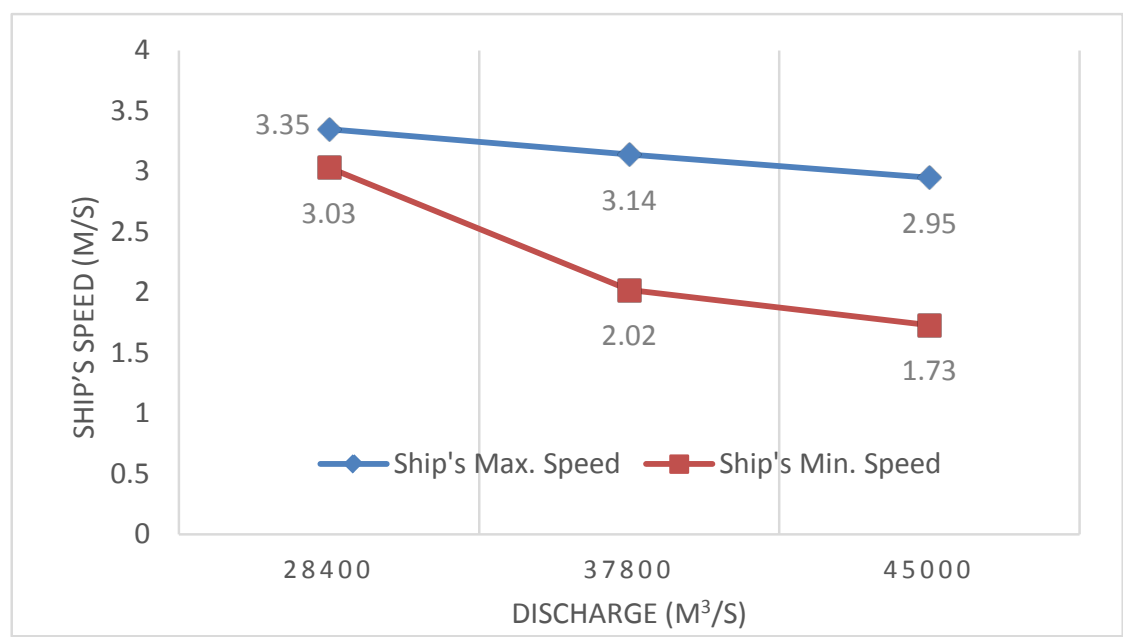

Figure 2. The ship's max. \& min. speed with discharges (1000 t, upstream). 
waterway as long as the careful driving.

\subsection{0 t Class Ship Model Test}

1) Upstream Situation

In $\mathrm{Q}=28,400 \mathrm{~m}^{3} / \mathrm{s}, \mathrm{Q}=37,800 \mathrm{~m}^{3} / \mathrm{s}$ and $\mathrm{Q}=45,000 \mathrm{~m}^{3} / \mathrm{s}$ these three kinds of flow test conditions, the ship sails upstream in the bridge waterway. Figure 4 shows the maximum rudder angle was $17.22^{\circ}, 20.46^{\circ}$ and $20.64^{\circ}$. These angles did not exceed the ship model test of rudder angle limit $\left(25^{\circ}\right)$. Figure 5 shows the minimum ship speed were $3.08 \mathrm{~m} / \mathrm{s}, 2.17 \mathrm{~m} / \mathrm{s}$ and $1.97 \mathrm{~m} / \mathrm{s}$, were significantly better than the minimum speed of ship model test safety limit $(0.4 \mathrm{~m} / \mathrm{s})$. And the minimum speed is also better than the Three Gorges Reservoir area ones which is not less than the requirements of $1.1 \mathrm{~m} / \mathrm{s}$.

2) Downstream Situation

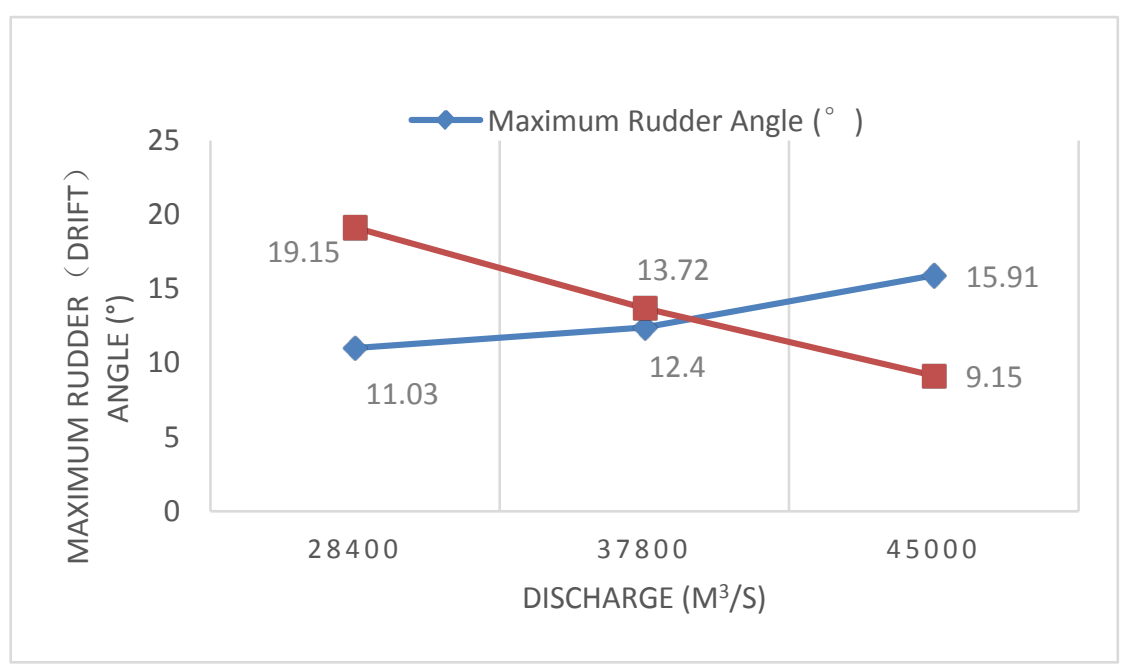

Figure 3. The maximum rudder \& drift angle with discharges (1000 t, downstream).

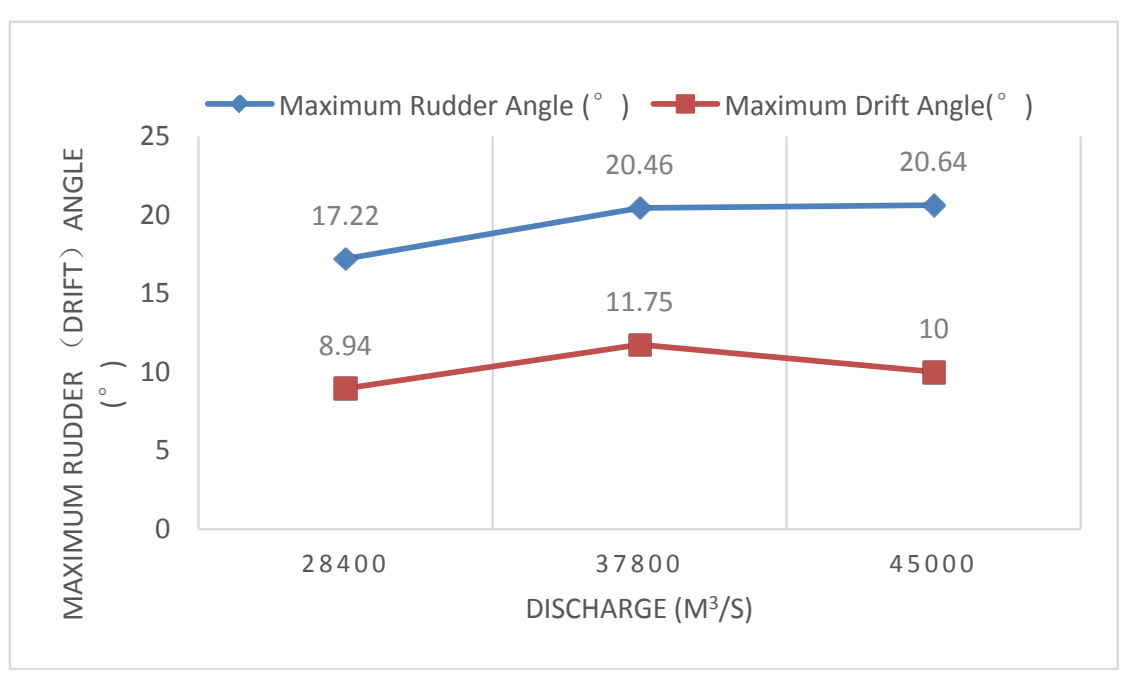

Figure 4. The maximum rudder \& drift angle with discharges (5000 t, upstream). 
In $\mathrm{Q}=28,400 \mathrm{~m}^{3} / \mathrm{s}, \mathrm{Q}=37,800 \mathrm{~m}^{3} / \mathrm{s}$ and $\mathrm{Q}=45,000 \mathrm{~m}^{3} / \mathrm{s}$ these three kinds of flow test conditions, the ship sails downstream in the bridge waterway. Figure 6 shows the maximum rudder angle was $11.02^{\circ}, 12.83^{\circ}$ and $16.30^{\circ}$. These angles did not exceed the ship model test of rudder angle limit $\left(25^{\circ}\right)$.

Ship model test results show that, after the anti-collision facility is set in the Wanzhou Yangtze River Highway Bridge, $5000 \mathrm{t}$ ship can safely pass through the bridge waterway as long as the careful driving.

\subsection{The Best Route, the Control Method \& the Difficulty of Navigation}

After the anti-collision facilities of Wanzhou Yangtze River Highway Bridge is set the navigation clearance is $310 \mathrm{~m}$, meet the I channel two-way navigation requirements. The hydraulic model test results that water drop and flow rate changes are small when the anti-collision facility is set before and after in the bridge area, and the water flow is

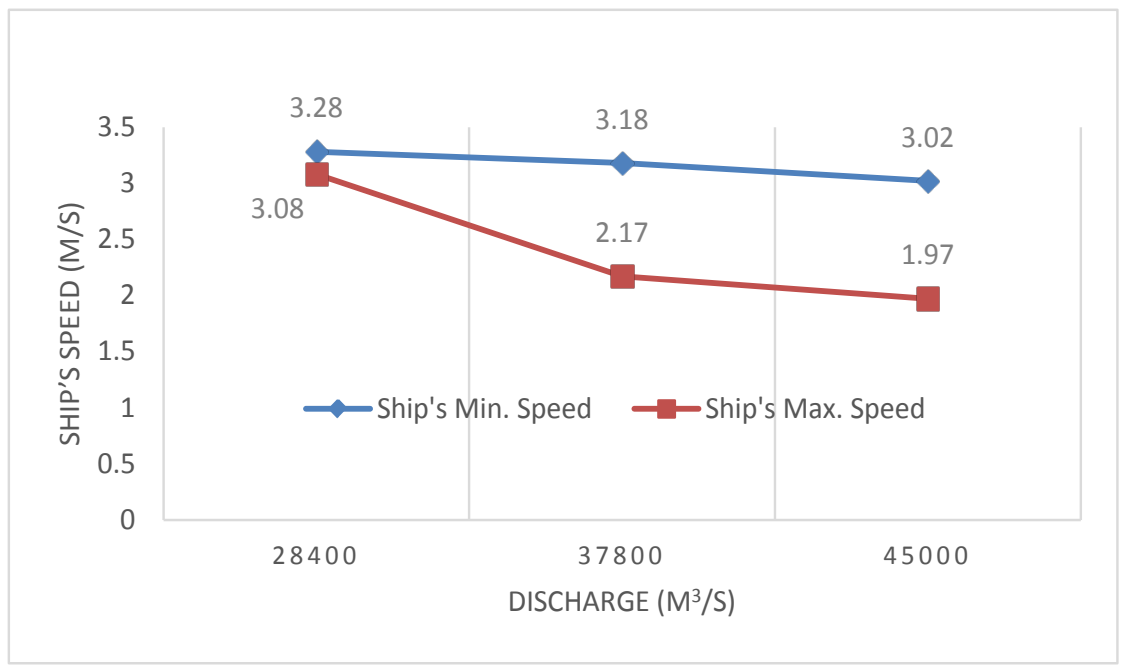

Figure 5. The ship's max. \& min. speed with discharges (5000 t, upstream).

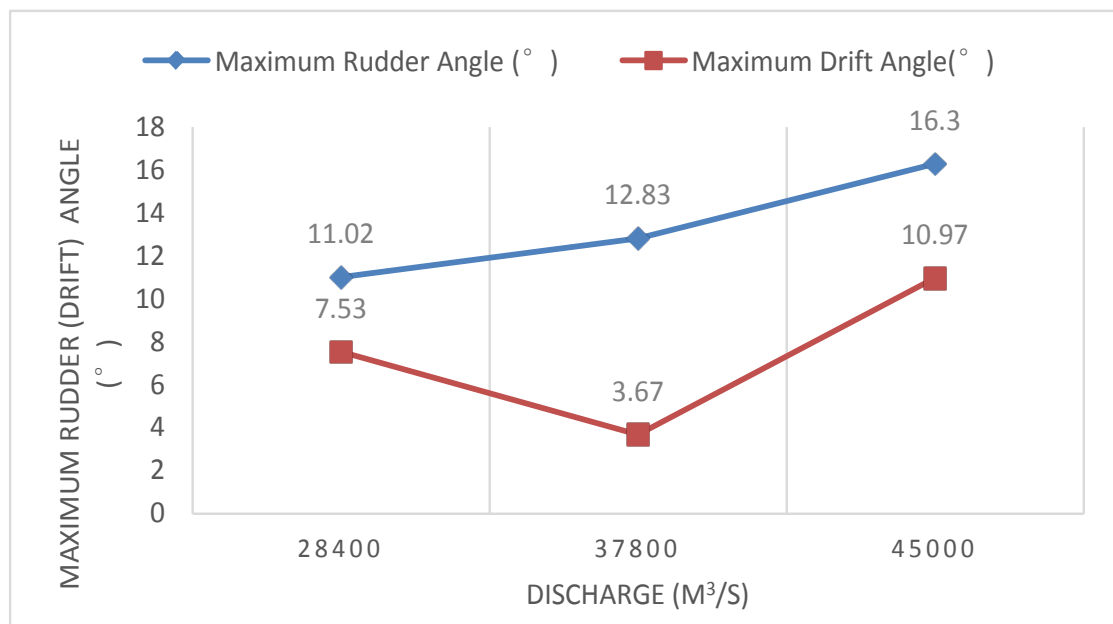

Figure 6. The maximum rudder $\&$ drift angle with discharges (1000 t, downstream). 
relatively near straight anti-collision facility. There is no obvious adverse flow and cross flow to influence the ship navigation safety.

1) Upstream Ships

Firstly, the ship should sail upstream using the shore flow in the traffic lanes along the side of river's left bank, keep the distance to shore about $150 \mathrm{~m}-200 \mathrm{~m}$. When the ship is $400 \mathrm{~m}$ from the downstream bridge axis, it should adjust the route and keep heading and position, then sail upstream along navigable waterway where the distance from the ship to anti-collision facility is approximately $50 \mathrm{~m}$. After the ship sailed out bridge waterway, it can sail as it sailed in normal waterways.

When the ship through the bridge waterways, the captain shall comply with the corresponding traffic regulations, operate carefully, maintain a certain distance to anti-collision facility and pay attention to the other ships. In the bridge waterway the ship is not allow to rendezvous.

2) Downstream Ships

Firstly, the ship should sail downstream in the traffic lanes along the side of river's right bank. When the ship is about $600 \mathrm{~m}-700 \mathrm{~m}$ from the upstream bridge axis, it should adjust the route and keep heading and position, then sail downstream along navigable waterway where the distance from the ship to anti-collision facility is approximately $105 \mathrm{~m}$. After the ship sailed out bridge waterway, it can sail as it sailed in normal waterways.

The difficulties of ship sail downstream is that the ship's speed is fast when it through the bridge waterway. So the ship should adjust the route and position well in advance and keep enough distance to anti-collision facility. In the bridge waterway the ship is not allow to rendezvous.

\section{Conclusions}

In the three kinds of water level, the minimum speed of $1000 \mathrm{t}$ ship and $5000 \mathrm{t}$ ship is obviously better than the minimum speed limit value of ship model test. The maximum rudder angle of the two types of ship is lower than the limit value of ship model test rudder angle. And the minimum speed is also better than the Three Gorges Reservoir area ones which is not less than the requirements of $1.1 \mathrm{~m} / \mathrm{s}$.

Ship model test results show that, in the test of the three kind of water level, the bridge area can meet the navigation requirements of $1000 \mathrm{t}$ and $5000 \mathrm{t}$ ship after the anti-collision facility construction of Wanzhou Yangtze River Highway Bridge. The facility does not interfere with the ship normal navigation in the Bridge Waterway.

\section{Acknowledgements}

This paper is funded by National Natural Science Foundation of China (No. 5140082), Application Fundamental Research Project of Ministry of Transport P. R. China (No. 2015319814040), the Fund of Chongqing Science \& Technology Commission (No. cstc2015jcyjA30010) and the Fund of Chongqing Educational Commission (No. KJZH14209). 


\section{References}

[1] Li, Y.B. and Wang, Y.L. (2004) Application of Technique of Ship Model Navigation Test in Study on Water Transport Engineering. Journal of Waterway and Harbour, 25, 8-13.

[2] Cai, C., Cai, X.Y. and Zhao, C.B. (2010) Research on Navigable Ship Model Experiment of Caojie Hydro-Junction Open Diversion Channel during Construction Period in Jialing River. Journal of Waterway and Harbor, 5, 492-496.

[3] Xiong, Y. and Liu, Z.H. (2013) Numerical Prediction of Propulsion Factors of Propelled Ship Model and Full Scale Ship. Journal of Ship Mechanics, 1, 14-18.

[4] Yan, W., Li, L. and Sun, J.B. (1999) Maneuverability Calibration Test of Tow Model for Studying Navigation of Three Gorges Project. Journal of Yangtze River Scientific Research Institute, 3, 1-4.

[5] Chen, M.D., Chen, M., Lin, Q. and Hai, X.S. (2009) Navigation Condition and Navigation Safety at Bridge District of Mountainous Rivers. Port \& Waterway Engineering, 8, 84-88.

Submit or recommend next manuscript to SCIRP and we will provide best service for you:

Accepting pre-submission inquiries through Email, Facebook, LinkedIn, Twitter, etc.

A wide selection of journals (inclusive of 9 subjects, more than 200 journals)

Providing 24-hour high-quality service

User-friendly online submission system

Fair and swift peer-review system

Efficient typesetting and proofreading procedure

Display of the result of downloads and visits, as well as the number of cited articles

Maximum dissemination of your research work

Submit your manuscript at: http://papersubmission.scirp.org/

Or contact eng@scirp.org 